\title{
The Role of Sport Passion Level of Athletes in Determining Love Attitude and Relation Satisfaction
}

\author{
Nazmi Bayköse ${ }^{1}$, Filiz Şahin ${ }^{2}$, Mehmet Emre Eryücel ${ }^{1}$, Ahmet Şahin ${ }^{2}$ \\ ${ }^{1}$ Akdeniz University Faculty of Sport Sciences, Turkey \\ ${ }^{2}$ Mehmet Akif Ersoy University Department of Physical Education and Sports, Turkey \\ Correspondence: Nazmi Bayköse, Faculty of Sport Sciences, Akdeniz University, Turkey.
}

Received: October 18, 2018

Accepted: January 25, 2019 Online Published: January 29, 2019

doi:10.11114/jets.v7i3.4001

URL: https://doi.org/10.11114/jets.v7i3.4001

\begin{abstract}
The purpose of this study is to examine the role of sport passion level of athletes in determinig love attitude and relation satisfaction. 218 athletes participated in this study as volunteers, 94 of the mare female $\left(X_{\text {age }}=20,46 \pm 3,12\right), 124$ of the mare male $\left(X_{\text {age }}=22,81 \pm 4,05\right)$ sport experience of athletes dealing with different branches of team and individual sports (football, basketball, volleyball, tennis, track and field, bike... etc.) is $110,15 \pm 54,59$ monts. To achieve the purpose of the study, Passion Scala was developed by Vallerand and his friends (2003) and it was adapted to Turkish culture by Kelecek (2013). Love Attitudes Scale (short form), was developed by Hendrick and Hendrick' in (1986, 1990), and it was adapted to Turkish culture by Buyuksahin and Hovardaoglu (2004), Fianlly, Relationship Assessment Scala which were developed by Hendrick (1988) and adapted to Turkish culture by Curun (2001) were used. For solution and interpretation of the datas, descriptive statistical methods; for independent samples T-test, One Way Anova test and Multiple Step wise regression analysis were used. Analysis performed by using SPSS and research significance was accepted as $\mathrm{P}<0,05$. As a result of this study, it has been observed that athletes' sport passion level sare important determiners of love attitude and relation satisfactions, as well as it has also been observed that athletes love attitude level safe determiners of relation satisfactions.
\end{abstract}

Keywords: love attitude, relation satisfaction, passion in sport

\section{Introduction}

Nowadays, many researchers are making investigations on the spiritual world of athletes' (Curran, 2013; Baykose, 2014; Bayköse et al., 2017; Bayköse et al., 2016; Gülşen et al.,2018; Eryücel, Sülün \& Şahan, 2018; Şahin, Bayköse \& Civar Yavuz, 2017). These investigations mostly focus on their psychological abilities and basically aim to improve athletes' performances (Vallerand et al. 2008; Hamilton and Fremour, 1985; Hanton and Jones, 1999; Harmison, 2006). When considered from this point of view, in addition to sportsmen's role as athletes, there have a social role as individuals in the society. At this point, it is obvious that the notion of "relationships", which is an indispensable part of social life, is a social truth for sportsmen as it is for other individuals.

It is a necessity for sportsmen to lead both their social and their career lives. At times, studies made on samples of sportsmen show that sportsmen have different passion levels for the sports they are doing. (Vallerand and Miquelon, 2007; Kelecek, 2013). It has been revealed through investigations that their passion levels play psychologically determinant role in determining their attitudes and behaviors during their performance. (Vallerand and Miquelon, 2007; Kelecek, 2013). As a result of the investigations made in the databases, which are Science Direct, Ulakbim, Elsiver and Thomson Reuters databases, 'with the keywords' Passion', 'Passion in sport" 'Love in sport" 'Love attitude in sport", 'Relation Satisfaction in sport', no research related to neither sportsmen's relation satisfaction levels nor their attitude to love has been found. In parallel with this information, in this study mainly sportsmen's attitude to love and relation satisfaction, which are the notions thought to be affecting their sports life directly while affecting their performances indirectly, will be analyzed.

When literally analyzed, close relationships can be understood by analyzing the reciprocal dependency that individuals have for one another (Rusbult et al., 2004). The context of love within "Close relationships", which is a concept that is called "bilateral relationships" in social psychology (Buyuksahin 2005; Karremans et al., 2003; Sells and Hargrave, 1998), has been investigated by many researchers for a long time (Sells and Hargrave, 1998; Karremans et al., 2003). Every culture contains love and close relationships within itself. One of these cultural surroundings is sports. Sports gathers 
different kinds of people bearing different kinds of traits. Though Love is a universal notion, the way that individuals experience it may differ according to cultural differences (Aronson et al., 2012). Different cultural backgrounds that individuals have may affect both their relation satisfaction level and their attitude to love (Neto et al., 2000).

According to Lee's (1988) Classification of Love, Love is analyzed under 6 different titles. In this classification, individuals are said to be selecting different types of love, which are passionate love style (eros), selfless love style (agape), posessive love style (mania), game-playing love style (ludus), companionate love style (storge), and practical love style (pragma). Lee (1988) also highlights in his classification that each one of the love types has its own features. There is a lot of information about styles of love, which attracted many researchers. Their close relationships with many factors in terms of relational concept and what these relationships mean in accordance with cause and effect relations have been revealed. Correlative studies, carried out by researchers, reveal the love style sand close relationships that are related with various factor sand also reveal what these relationships mean in terms of cause and effect. (Zeigler-Hillandcol, 2015; Thompson, 1996, Kanemakaandcol, 2004; Honari and Saremi, 2015).

Another factor that we have taken into account while conducting the research is relation satisfaction. Satisfaction is a personal assessment that individuals make about their relationships. The experiences of individuals affect the quality of their relationships and their compatibility in relationships during their adulthood (Furman, 2002; Sabetelli, 1988). It is also stated that positive experiences that individuals underwent allow them to get satisfied in their relationships while the negative ones do not allow them to do so. Being satisfied in a relationship is significant both for individuals' happiness and the longevity of the relationship (Taylor, Peplau and Sears, 2003).On the other hand, the experiences of individuals' effect both the quality and the compatibility of their relationships during their adulthood (Furman, 2002; Sabetelli, 1988).

As it is stated in the relevant article, it is revealed in the research that love types and satisfaction level in a relationship are affected by both positive and negative factors. (Zeigler-Hill et al. 2015; Honari and Saremi, 2015; Zeigler-Hill and Abraham, 2006). Based on the claim by Vallerad et al. (2006) that there is a link between positive and negative emotions and harmonious and obsessive passions, the aim of this research is to investigate the role of their passion for sports in determining attitude to love and relation satisfaction with the sample of sportsmen.

\section{Materials and Methods}

\subsection{Research Design and Analysis}

The research was based on the relational survey model. "Relational survey model" is applied in the research. "Relational Survey Model" is defined as a search model that aims to determine the level of simultaneous change between two or among more variables. (Karasar, 1999). Descriptive Statistical techniques, t-test, which is used for independent examples, One Way Anova test and Multiple Stepwise Regression Analysis are applied in the study while analyzing and commenting on the data. The analyses are conducted with SPSS package and in the study the significance level is taken as $\mathrm{P}<0.05$.

In this study, sportsmen's attitude to love and their relation satisfaction levels are found to be affected by their passion for sports. As the analysis of sports effect on determining their attitude to love and their satisfaction level is a relational issue, variables such as gender, age and sports experience are used in the study to see whether the results change in relation with these variables (Karasar, 1999).

\subsection{Participants}

In total 218 heterosexual athletes $\left(X_{\text {age }} 21.79 \pm 3.85\right), 94$ of whom are females $\left(X_{\text {age }}=20,46 \pm 3,12\right)$ while 124 of whom are males $\left(X_{\text {age }} 22.81 \pm 4.05\right)$, volunteered to participate in this study. Sports experience of athletes dealing with different branches of sports (football, basketball, volleyball, tennis, athleticism, bike... etc.) is $110.15 \pm 54.59$ months.

\subsection{Measuring Instruments}

In this study, the socio-demographic information is gathered via personal information sheet, which is developed by the researcher. To achieve the goal of the study, Passion Scale, which is developed by Valleard et al (2003) and adapted to Turkish by Kelecek (2013), Love Attitudes Scale-Las: Short Form, which is developed by Hedrick and Hendrickin $(1986,1990)$ and adapted to Turkish by Buyuksahin and Hovadaroğlu (2004), and The Relationship Assessment Scale which is developed by Hendrick (1988) and adapted to Turkish by Curun (2001) are used.

The scale forms, which are administered in the study in order to assess athletes' love styles, satisfaction levels and their passion for sports, are mentioned in the following.

\section{Results}

As a result of Multiple Stepwise Regression Analysis, sub dimension of obsessive passion $(\beta=0.15$; $P>0.05)$ is not included in the model. According to the result of the analysis, the harmony between scores of harmonious passion and scores of relation satisfaction has been found. There is a positive relation between harmonious passion and satisfaction 
level $(\mathrm{R}=0.48 ; \mathrm{F}(\mathrm{vif}=1.566)=31.404 ; \mathrm{p}<0.05)$. A positive link between harmonious passion and satisfaction is found $(\beta=0.38 ; \mathrm{p}<0.05)$. The total score of sportsmen's harmonious passion explains $23 \%$ of all the scores, related to satisfaction level $(\mathrm{R} 2=0.23 ; \mathrm{p}<0.05)$ (Table 1$)$.

Table 1. The Results of the Regression Analyses Concerning the Effect of Sportsmen's Passion Level on Determining Their Relation Satisfaction

\begin{tabular}{l|l|l|l}
\hline & $B$ & $T$ & $P$ \\
\hline Harmonious Passion & 0.376 & 5.010 & 0.000 \\
\hline Obsessive Passion & 0.142 & 1.895 & 0.059 \\
\hline
\end{tabular}

$\mathrm{R}=0.475 ; \mathrm{R} 2=0.226 ;$ Adjusted $\mathrm{R}^{2}=0.219 ; \mathrm{F}=31.404 ; \mathrm{p}=0.000$

Table 2. The Results of the Regression Analyses Concerning the Effect of Sportsmen's Satisfaction Level on Determining Their Selfless Love Attitude

\begin{tabular}{l|l|l|l}
\hline & $B$ & $T$ & $P$ \\
\hline Harmonious Passion & 0.107 & 1.316 & 0.190 \\
\hline Obsessive Passion & 0.228 & 2.809 & 0.005 \\
\hline $\mathrm{R}=0.305 ; \mathrm{R} 2=0.093 ;$ Adjusted $\mathrm{R}^{2}=0.085 ; \mathrm{F}=11.015 ; \mathrm{p}=0.000$ & &
\end{tabular}

As a result of Multiple Stepwise Regression Analysis, sub dimension of obsessive passion $(\beta=0.15$; $P>0.05)$ is not included in the model. According to results of the analysis, a link between scores of obsessive passion and selfless love attitude has been found $(\mathrm{R}=0.31 ; \mathrm{F}(\mathrm{vif}=1.566)=11.015 ; \mathrm{p}<0.05)$. A positive relation between obsessive passion and selfless love has been found $(\beta=0.23 ; p<0,05)$. The scores, which are related to obsessive passion, explains $9 \%$ of the scores which are related to selfless lovestyle $(\mathrm{R} 2=0.09 ; \mathrm{p}<0.05)$.(Table 2$)$.

Table 3. The Results of the Regression Analyses Concerning the Effect of Sportsmen's Satisfaction Level on Determining Their Companionate Love Attitude

\begin{tabular}{l|l|l|l}
\hline & $B$ & $T$ & $P$ \\
\hline Harmonious Passion & 0.027 & 0.328 & 0.743 \\
\hline Obsessive Passion & 0.306 & 3.784 & 0.000 \\
\hline R $0.322 ; \mathrm{R} 2=0.104 ;$ Adjus
\end{tabular}

$\mathrm{R}=0.322 ; \mathrm{R} 2=0.104 ;$ Adjusted $\mathrm{R}^{2}=0.096 ; \mathrm{F}(\mathrm{vif}=1.566)=12.468 ; \mathrm{p}=0.000$

According to multiple stepwise regression analysis, subdimension of harmonious passion is not included in the model $(\beta=0.03 ; \mathrm{P}>0.05)$. As a result of the analysis, a link between companionate love attitude and obsessive passion scores of sportsmen has been found $(\mathrm{R}=0.32 ; \mathrm{F}(\mathrm{vif}=1.566)=12,468 ; \mathrm{p}<0.05)$. There is a positive relation between obsessive passion and companionate love attitude $(\beta=0.31 ; \mathrm{p}<0.05)$. The obsessive passion scores of the sportsmen explain $\% 9$ of the total score related to companionate love attitude $(\mathrm{R} 2=0.10 ; \mathrm{p}<0.05)$. (Table 3$)$.

Table 4. The Results of the Regression Analyses Concerning the Effect of Athletes' Satisfaction Level on Determining Their Passionate Love Attitude

\begin{tabular}{l|l|l|l}
\hline & $B$ & $T$ & $P$ \\
\hline Harmonious Passion & 0,264 & 3,270 & 0,001 \\
\hline Obsessive Passion & 0,085 & 1,054 & 0,293 \\
\hline
\end{tabular}

$\mathrm{R}=0.323 ; \mathrm{R} 2=0.104 ;$ Adjusted $\mathrm{R}^{2}=0.096 ; \mathrm{F}=12.487 ; \mathrm{p}=0.000$

As a result of Multiple Stepwise Regression Analysis, subdimension of obsessive passion is not included in the model $(\beta=0.09 ; \mathrm{P}>0.05)$. According to results of analysis, a relation between sportsmen's harmonious passion and their passionate love attitude scores has been found $(\mathrm{R}=0.32 ; \mathrm{F}$ (vif=1.566) $=12.487$; $\mathrm{p}<0.05)$. A rational positive link between harmonious passion and passionate has been detected $(\beta=0.26 ; \mathrm{p}<0.05)$. Sportsmen's harmonious passion scores explain $10 \%$ of the total scores related to passionate love scores $(R 2=0.10 ; p<0.05)$. (Table 4).

Table 5. The Result of Regression Analyses Concerning the Effect of Sportsmen's Satisfaction Level on Determining Their Practical Love Attitude

\begin{tabular}{l|l|l|l}
\hline & $B$ & $T$ & $P$ \\
\hline Harmonious Passion & 0.004 & 0.042 & 0.967 \\
\hline Obsessive Passion & 0.086 & 1.016 & 0.311 \\
\hline R $0.089 ;$ R2 $0.008 ;$ Adjut
\end{tabular}

$\mathrm{R}=0.089 ; \mathrm{R} 2=0.008 ;$ Adjusted $\mathrm{R}^{2}=0.001 ; \mathrm{F}=0.850 ; \mathrm{p}=0.000$

According to results of the multiple stepwise regression analysis, the subdimensions of both harmonious love $(\beta=0.09$; $\mathrm{P}>0.05)$ and obssesive passion $(\beta=0.09 ; \mathrm{P}>0.05)$ are not included in the model. As the results of the analysis suggest, a link among sportsmen's harmonious and obssesive passion scores and practical love attitude is not found ( $\mathrm{R}=0.09 ; \mathrm{F}$ $($ vif $=1.566)=0.850 ; \mathrm{p}>0.05)$. (Table 5). 
Table 6. The Results of Regression Analyses Concerning the Effect of Athletes' Satisfaction Level on Determining Their Game-Playing Love

\begin{tabular}{l|l|l|l}
\hline & $B$ & $T$ & $P$ \\
\hline Harmonious Passion & 0.187 & 2.379 & 0.018 \\
\hline Obsessive Passion & 0.477 & 6.080 & 0.000 \\
\hline
\end{tabular}

$\mathrm{R}=0.394 ; \mathrm{R} 2=0.155$; Adjusted $\mathrm{R}^{2}=0.147 ; \mathrm{F}=19.757 ; \mathrm{p}=0.000$

According to multiple stepwise regression analysis, a link among harmonious passion, obsessive passion and game-playing love style has been found $\mathrm{R}=0.39 ; \mathrm{F}(3.659)=19.757 ; \mathrm{p}<0.05)$. Positive links not only between harmonious passion and game-playing love style $(\beta=0.19 ; \mathrm{p}<0.05)$ but also between obsessive passion and game-playing love style have been detected $(\beta=0.48 ; \mathrm{p}<0.05)$. The total scores of harmonious passion and obsessive passion explain \% 16 of the total variance related to game-playing love style $(R 2=0.16 ; p<0.05)$. (Table 6$)$.

Table 7. The Results of the Regression Analyses Concerning the Effect of Sportsmen's Satisfaction Level on Determining Their Possessive Love Attitude

\begin{tabular}{l|l|l|l}
\hline & $B$ & $T$ & $P$ \\
\hline Harmonious Passion & 0,077 & 1,077 & 0,282 \\
\hline Obsessive Passion & 0,086 & 1,016 & 0,000 \\
\hline $\mathrm{R}=0.553 ; \mathrm{R} 2=0.306 ;$ Adjusted $\mathrm{R}^{2}=0.300 ; \mathrm{F}=47.450 ; \mathrm{p}=0.000$ &
\end{tabular}

$\mathrm{R}=0.553 ; \mathrm{R} 2=0.306 ;$ Adjusted $\mathrm{R}^{2}=0.300 ; \mathrm{F}=47.450 ; \mathrm{p}=0.000$

The subdimension of harmonious passion is not included in the model $\beta=0.08 ; \mathrm{P}>0.05$ ). As a result of the analysis, a link between sportsmen's obsessive passion scores and possessive love attitude has been realized $(\mathrm{R}=0.55 ; \mathrm{F}$ (vif $=1.566$ ) $=47.450 ; \mathrm{p}<0.05)$. A positive link between obsessive passion and possessive love style is detected $(\beta=0.60 ; \mathrm{p}<0.05)$. The total of sportsmen's obsessive passion scores explains $31 \%$ of the total variance related to sportsmen's possessive love style ( $R 2=0.31 ; \mathrm{p}<0.05)$. (Table 7).

Table 8. The Results of the Regression Analyses Concerning the Role of Sportsmen's Attitude To Love in Determining Their Satisfaction Level in Their Relationships

\begin{tabular}{llll}
\hline Model & $B$ & $T$ & $P$ \\
\hline Selfless Love Style & .124 & 1.422 & .156 \\
\hline Companioate Love Style & -.106 & -1.507 & .133 \\
\hline Passionate Love Style & .503 & 6.941 & .000 \\
\hline Practicle Love Style & -.187 & -2.765 & .006 \\
\hline Game-playing Love Style & -.021 & -.282 & .779 \\
\hline Possesive Love Style & .030 & .408 & .683 \\
\hline $\mathrm{R}=0.521 ; \mathrm{R} 2=0.271 ;$ Adjusted $\mathrm{R}^{2}=0.250 ; \mathrm{F}=13.086 ; \mathrm{p}=0.000$ & &
\end{tabular}

According to multiple stepwise regression analysis, the subdimensions of selfless love style $(\beta=0.12 ; \mathrm{P}>0.05)$, companiate love style $(\beta=-0.11 ; \mathrm{P}>0.05)$, game-playing love style $(\beta=-0.02 ; \mathrm{P}>0.05)$ and possesive love style $(\beta=0.03 ; \mathrm{P}>0.05)$ are not included in the model. As a result of the analysis, a positive link among satisfaction levels of athletes' and their passionate and practicle love attitudes has been detected $(\mathrm{R}=0.52 ; \mathrm{F}=13.086 ; \mathrm{p}<0.05)$. Moreover, while there is a positive link between satisfaction level and passionate love attitude $(\beta=0.50 ; p<0.05)$, a negative link, between satisfaction level and practicle love attitude, has been etected $(\beta=-0.19 ; \mathrm{p}<0,05)$. The total scores of sportsmen's passionate love attitude and practile love attitude explain $\% 27$ of the total varience related to satisfaction level $(R 2=0.27 ; \mathrm{p}<0.05)$ (Table 8).

\section{Discussion}

The passion for sports can said to be playing a selective role while determining attitude to love. In this context, it is observed that the harmonious passion that athletes have for sports is a predictor of their relation satisfaction. When the relevant article is analyzed, it can be said that the results of the study, in which two factoral passion model is applied to assess the level of passion for the internet, conducted by Seguin-Levesque et al (2003) have parallels with our findings. In the study, it is reported that individuals with harmonious passion have much more qualified close relationships than individuals who have the obsessive passion for the internet. Moreover, harmonious passion is found to be positively affecting the quality of individuals' relationships. In this context, the results are similar to our findings dealing with the quality of relationships. Moreover, the result concluded in the study supports two factoral passion structure. As Vallerand and Blanchard (1999) marked, harmonious passion is liable to bear positive results. And so, the findings, obtained by Blanchard and Vallerand (1998) along with the findings of Blanchard and Vallerand (1999) also support our research. In accordance with this relation that has been obtained, core identification hypothesis, which makes up the basis of two-dimensional passion hypothesis may help to explain our research findings. (Deci and Ryan 1985, 1991; Ryan and Deci 2000). Because the relationship satisfaction level requires motivation and the relationship between individuals is based on this motivation (Deci and Ryan 1985, 1991; Ryan and Deci 2000). At least according to our results, the harmonious 
passion that an individual has for sports can be said to have a positive effect on determining the relationship satisfaction.

It is observed that while obsessive passion is related to selfless love, possessive love, and companionate love, harmonious passion is the only predictor of passionate love. Moreover, it is observed that both harmonious and obsessive passions are of effect while determining the game-playing love attitude. When the article in parallel with these findings are investigated; the findings obtained show paralellism with the research findings carried out by Bilge and Tezer (2008) in terms of sub-dimensioned consistent passion. According to Bilge and Tezer's findings (2008), the more the level of negative emotions increases, the more passionate love decreases. In other words, it is discovered that the more the level of positive emotions increases, the more passionate love attitude increases.

In another research, conducted by Zeigler-Hill et al. (2015), love is found to be increasing the individuals' self-respect. In the article by Buyuksahin and Hovadaroğlu (2004), it is stated that there is a strong link between passionate love and happiness. In addition to this, the results concluded from Kelecek's (2013) findings, which suggest that both obsessive and harmonious passions are predictors of optimal emotional status, revealed that passionate love is a predictor of harmonious passion in sportsmen. According to this result, it is not wrong to say that harmonious passion will contribute positively to sportsmen's performance. Companionate love is also said to be related to positive psychological factors in different studies (Zeigler-Hill et al. 2015). Therefore, it is not wrong to state that the article also supports the results.

When analyzed in terms of obsessive passion, obsessive passion is found to be the predictor of both possessive and selfless love styles in a study conducted by Bilge and Tezer (2008). As it is stated by Vallerand and Blanchard (1999) obsessive passion is liable to bear negative results. In general, the studies, in the literature, focus on selfless and posessive love styles. Thompson (1996) have found out that selfless love is highly related to compulsive and obsessive personal traits. In another research (Kanemasa et al, 2004; Honari and Saremi 2015), which investigated the link between different types of love and emotional experiences, it is found that selfless love is related to such negative traits as anxiety, jealousy, and incompatibility. Possessive love style is also found to be linked to negative psychological factors. (Zeigler-Hill and Abraham, 2006; Foster et al. 2007; Dutton Van Ginkel and Landolt 1996; Feeney and Noller 1990; Zeigler-Hill et al. 2015).

In the light of these results, it can be asserted that individuals with obsessions prone to adapt to possessive and selfless love styles.

It is observed that passionate love and practical love play roles while determining satisfaction level in a relationship. It is revealed that while passionate love has a positive effect on increasing the level of satisfaction in a relationship, practical love is of a negative predictor role while determining the level of relation satisfaction. In parallel with this result, when the relevant article is analyzed, it can be said that Curun's (2001) findings support our results. In other words, it is obvious that our results support Curun's (2001) research with the sample of sportsmen.

In conclusion, generally it is considered that the psychological passion that sportsmen have for sports has a role while determining their attitude in their relationships. After all, in this research, such questions as "Does sportsmen's passion for sports have a determinant role in determining their attitude to love?", “ Does the attitude of sportsmen to love have an effect while determining their relation satisfaction?" are tried to be answered.

In the light of these questions, it is revealed that sportsmen's passionate attitude to love, which can either be harmonious or obsessive, goes in parallel with their attitude to sports. In this regard, it can be said that passion for sports is an indirect factor that has an effect on sportsmen's attitudes and their emotional status. That is, sportsmen's attitude in a relationship is thought to be affected by their attitude towards sports.

Starting from these questions, it is observed that sportsmen's harmonious or obsessive attitudes affect their romantic relationships in the same way. (That is, if they are of obsessive traits, they act obsessively in their relationships or if they are of harmonious trait, they act harmoniously in their relationships.)In this context, when the fact that passion can be determined by personal traits and sportsmen's emotional status is taken into account, passion for sports is thought to be playing an indirect determinant role. It is thought that sportsmen can show a similar attitude, which they show to the sports, to their close relationships.

The results helped us to understand the fact that sportsmen's passion for sports, which can either be harmonious or obsessive, determines both their attitude and their relation satisfaction level.

\section{References}

Arnold, M. E., \& Thompson, B. (1996). Love Style Perceptions in Relation to Personality Function. Journal of Social Behavior And Personality, 11(3), 425-438.

Aronson, E., Wilson, T. D., Akert, R. M., \& Gündüz, O. (2012). Sosyal psikoloji. Kaknüs Yayınları.

Bayköse, N. (2014). Sporcularda Kendinle Konuşma ve İmgeleme Düzeyinin Optimal Performans Duygu Durumunu Belirlemedeki Rolü. Yüksek Lisans Tezi. Selçuk Üniversitesi, Sağlık Bilimleri Enstitüsü, Beden Eğitimi ve Spor 
Anabilim Dal1. Konya.

Bayköse, N., Civar Yavuz, S., Çoban, M., Şahan, H., \& Certel, Z. (2016). Role of self talk in prediction of passion level in physical education class environment. Turkish Online Journal of Educational Technology, (December Special Issue), 445-452.

Bayköse, N., Yavuz, S. C., Keskin, P., \& Kılınç, M. (2017). Sporcularda benlik saygısı ve tutkunluğun psikolojik sağlamlığı yordama da ki rolü: Bir yapısal eşitlik modeli uygulaması. International Journal of Sport, Exercise \& Training Sciences, 3(4), 169-177

Bilge, U., \& Tezer, E. (2008). Aşka İliskin Tutum Biçimlerinin Olumlu Ve Olumsuz Duyguları Yordayıcıllğı. Türk Psikolojik Danısma ve Rehberlik Dergisi, 3(30), 19-29.

Blanchard, C. B., \& Vallerand, R. J. (1998, May). Harmonious and obsessivepassions: A look at subjective well-being. Poster session presented at the meeting of the American Psychological Society, Washington, DC.

Büyükşahin, A. (2005). Çok boyutlu İlişki Ölçeği: Geçerlilik ve Güvenilirlik Çalışması. Türk Psikiyatri Dergisi, 16(2), 97-105.

Büyükşahin, A. (2006). Yakın İlişkilerde Bağlanım: Yatırım Modelinin Bağlanma Stilleri Ve Bazı İlişkisel Değişkenler Yönünden İncelenmesi. Yayımlanmamış Doktora Tezi, Ankara Üniversitesi Sosyal Bilimler Enstitüsü, Ankara.

Büyükşahin, A., \& Hovardaoğlu, S. (2004). Çiftlerin Aşka İlişkin Tutumlarının Lee'nin Çok Boyutlu Aşk Biçimleri Kapsamında İncelenmesi. Türk Psikoloji Dergisi, 19(54), 59-72.

Curran, T., Appleton, P. R., Hill, A. P., \& Hall, H. K. (2013). The Mediating Role Of Psychological Need Satisfaction İn Relationships Between Types Of Passion For Sport And Athlete Burnout. Journal Of Sports Sciences, 31(6), 597-606. https://doi.org/10.1080/02640414.2012.742956

Curun, F. (2001). The Effects of Sexism and Sex Role Orientation on Romantic Relationship Satisfaction, Yayımlanmamış Yüksek Lisans Tezi, Ortadoğu Teknik Üniversitesi Sosyal Bilimler Enstitüsü Psikoloji Bölümü, Ankara.

Deci, E. L., \& Ryan, R. M. (1985). Intrinsic motivation and self-determination in human behavior. New York, NY Plenum. https://doi.org/10.1007/978-1-4899-2271-7

Deci, E. L., \& Ryan, R. M. (1991). A motivational approach to self Integration in personality. In R. Dienstbier (Ed.), Nebraska Symposium on Motivation: Vol. 38. Perspectives on motivation (pp. 237-288). Lincoln, NE: University of Nebraska Press.

Dutton, D. G., Van Ginkel, C., \& Landolt, M. A. (1996). Jealousy, intimate abusiveness, and intrusiveness. Journal of Family Violence, 11, 411-423. https://doi.org/10.1007/BF02333425

Eryücel, M. E., Sülün, Ö., \& Şahan, H. (2018). Hakemlerin Empati ve Öfke Düzeylerinin Çeşitli Değişkenlere Göre İncelenmesi. Akdeniz Spor Bilimleri Dergisi, 1(2), 90-98.

Feeney, J. A., \& Noller, P. (1990). Attachment style as a predictor of adult romantic relationships. Journal of Personality and Social Psychology, 58, 281-291. https://doi.org/10.1037/0022-3514.58.2.281

Foster, J., Kernis, M., \& Goldman, B. (2007). Linking adult attachment to self-esteem stability. Self and Identity, 6, 6473. https://doi.org/10.1080/15298860600832139

Furman, W. (2002). The Emerging Fi Eld Of Adolescent Romantic Relationships. Current Directions In Psychological Science, 11, 117-180. https://doi.org/10.1111/1467-8721.00195

Gülşen, D. B. A., Yıldız, A. B., Bayköse, N., \& Eryücel, E. (2018). Bireysel ve Takım Sporu Yapan Spor Bilimleri Fakültesi Öğrencilerinin Kendinle Konuşma Düzeylerinin Çeşitli Değişkenlere Göre İncelenmesii. Akdeniz Spor Bilimleri Dergisi, 1(2), 58-66.

Hamilton, S. A., \& Fremour, W. J. (1985). Cognitive Behavioral Training for College Basket-Ball Free-Throw Performance. Cognitive Therapy and Research, 9, 479-483. https://doi.org/10.1007/BF01173095

Hanton, S., \& Jones, G. (1999). The Effects of a Multimodal İntervention Program on Performers: I1. Training the Butterflies to Fly İ Formation. The Sport Psychologist, 13, 22-41. https://doi.org/10.1123/tsp.13.1.22

Harmison, R. J. (2006). Peak Performance İn Sport: Identifying İdeal Performance States and Developing Athletes' Psychological Skills. Professional Psychology: Research and Practice, 3, 233-243. https://doi.org/10.1037/0735-7028.37.3.233

Hendrick, C., \& Hendrick, S. (1986). A Theory and Method of Love. Journal of Personality and Social Psychology, 
50(2), 392-402. https://doi.org/10.1037/0022-3514.50.2.392

Hendrick, C., \& Hendrick, S. (1990). A Relationship-Specific Version of The Love Attitude Scale. Journal of Social Behavior And Personality, 5, 239-254.

Hendrick, C., Hendrick, S., \& Dicke, A. (1998). The Love Attitude Scale: Short Form. Journal of Social and Personal Relationships, 15, 147-159. https://doi.org/10.1177/0265407598152001

Honari, B., \& Saremi, A. A. (2015). The Study Of Relationship Between Attachment Styles And Obsessive Love Style. Procedia-Social and Behavioral Sciences, 165, 152-155. https://doi.org/10.1016/j.sbspro.2014.12.617

Kanemasa, Y., Taniguchi, J., Daibo, I., \& Ishimori, M. (2004). Love Styles and Romantic Love Experiences İn Japan. Social Behavior And Personality, 32(3), 265-291. https://doi.org/10.2224/sbp.2004.32.3.265

Karasar, N, (2009). Bilimsel Araştırma Yöntemleri (15. Baskı), Ankara: Nobel Yayın Dağıtım

Karremans, J. C. K., Van Lange, P. A., Ouwerkerk, J. W., \& Kluwer, E. S. (2003). When Forgiving Enchances Psychological Well-Being: The Role Of İnterpersonal Commitment. Journal of Personality And Social Psychology, 84, 1011-1026. https://doi.org/10.1037/0022-3514.84.5.1011

Kelecek, S. (2013). Sporcuların Tutkunluk Düzeylerinin; Optimal Performans Duygu Durumu, Güdüsel Yönelim ve Hedef Yönelimini Belirlemedeki Rolü. Yüksek Lisans Tezi. Başkent Üniversitesi, Sağlık Bilimleri Enstitüsü. Egzersiz ve Sportif Performans Anabilim Dalı. Ankara.

Kelecek, S., \& Aş̧̧ı, F. H. (2013). "Tutkunluk Ölçeği"nin Üniversite Sporcuları İçin Geçerlilik Ve Güvenilirlik Çalışması. Turkiye Klinikleri Journal of Sports Sciences, 5(2), 80-85.

Lee J. A. (1988). Love Styles. In Psychology of Love (Eds RJ Sternberg, ML Barnes):38-67. New Haven, Yale University Press.

Neto, F., Mullet, E., Deschamps. J. C., Barros, J., Benvindo, R., Camino, L., Falconni, A, Kagibanga, V., \& Machado, M. (2000). Cross-cultural variations in attitudes toward love. Journal of Cross-Cultural Psychology, 31(5), 626-635. https://doi.org/10.1177/0022022100031005005

Rusbult, C. E., Kumashiro, M., Coolsen, M. K., \& Kirchner J. L. (2004). Interdependence, Closeness, And Relationships, In Mashek, D. J and Aron, A. Handbook of Closeness and Intimacy, (Pp. 137-161), New Jersey: Lawrence Erlbaum Associates.

Ryan, R. M., \& Deci, E. L. (2000). Self-determination theory and the facilitation of intrinsic motivation, social development, and well-being. American Psychologist, 55, 68-78. https://doi.org/10.1037/0003-066X.55.1.68

Sabatelli, R., N. (1988). Exploring Relationship Satisfaction: A Social Exchange Perspective on the Interdependence Between Theory, Research, And Practice. Family Relations, 37(2), 217-222. https://doi.org/10.2307/584323

Şahin, A., Bayköse, N., \& Civar Yavuz, S. (2017). Does the undergraduate athletese self talk levels affect imagery levels. Turkish Online Journal of Educational Technology, (December Special Issue) 867-871.

Segun-Levesque, C., Lalıberte, M. L. N., Pelletıer, L. G., Blanchard, C., \& Vallerand, R. J. (2003). Harmonious and Obsessive Passion Fort He İnternet: Their Associations with The Couple's Relationship. Journal of Applied Social Psychology, 33(1), 197-221. https://doi.org/10.1111/j.1559-1816.2003.tb02079.x

Sells, J. N., \& Hargrave, T. D. (1998). Forgiveness: A Review of The Theoretical and Empirical Literature. Journal of Family Therapy, 20, 21-36. https://doi.org/10.1111/1467-6427.00066

Stackert, R. A., \& Bursik, K. (2003). Why I Unsatisfied? Adult Attachment Style, Gendered İrrational Relationship Beliefs, And Young Adult Romantic Relationship Satisfaction. Personality Andindividual Differences. 34. 1419-1429. https://doi.org/10.1016/S0191-8869(02)00124-1

Taylor, S. E., Peplau, L. A., \& Sears, D. O. (2003). Social Psychology (11th. Ed.) New Jersey: Prentice-Hall.

Vallerand, R. J., \& Blanchard, C. B. (1999, June). Toward a psychology of passion. Paper presented at the annual conference of the American Psychological Society, Denver, CO.

Vallerand, R. J., \& Miquelon, P. (2007). Passion İn Sport: Theory, Research, And Applications. In S. Jowett \& D. Lavallee (Eds.), Social Psychology İn Sport. Champaign, IL: Human Kinetics.

Vallerand, R. J., Blanchard, C., Mageau, G. A., Koestner, R., Ratelle, C., Leonard, M., \& et al. (2003). Les Passions De L'ame: On Obsessive and Harmonious Passion. J. Pers Soc Psychol. 85(4), 756-767. https://doi.org/10.1037/0022-3514.85.4.756

Vallerand, R. J., Mageau, G. A., Elliot, A. J., Dumais, A., Demers, M. A., \& Rousseau, F. (2008). Passion and 
Performance Attainment in Sport. Psychology of Sport And Exercise, 9(3), 373-392. https://doi.org/10.1016/j.psychsport.2007.05.003

Vallerand, R. J., Rousseau, F. L., Grouzet, F. M. E., Duma1s, A., Grenıer, S., \& Blanchard, C. M. (2006). Passion İn Sport: A Look At Determinants And Affective Experiences. Journal Of Sport \& Exercise Psychology, 28, 454-478. https://doi.org/10.1123/jsep.28.4.454

Zeigler-Hill, V., \& Abraham, J. (2006). Borderline personality features: Instability of self-esteem and affect. Journal of Social and Clinical Psychology, 25, 668-687. https://doi.org/10.1521/jscp.2006.25.6.668

Zeigler-Hill, V., Britton, M., Holden, C. J., \& Besser, A. (2015). How Will I Love You? Self-Esteem Instability Moderates the Association Between Self-Esteem Level And Romantic Love Styles. Self and Identity, 14(1), 118-134. https://doi.org/10.1080/15298868.2014.960445.

\section{Copyrights}

Copyright for this article is retained by the author(s), with first publication rights granted to the journal.

This is an open-access article distributed under the terms and conditions of the Creative Commons Attribution license which permits unrestricted use, distribution, and reproduction in any medium, provided the original work is properly cited. 